African Crop Science Journal by African Crop Science Society is licensed under a Creative Commons Attribution 3.0 Uganda License. Based on a work at www.ajol.info/ and www.bioline.org.br/cs DOI: http://dx.doi.org/10.4314/acsj.v24i1.6S

\title{
BOVINE TUBERCULOSIS IN EAST AFRICA
}

\author{
J.M. MUGAMBI, S.G. OMWENGA, H.O. WESONGA, P. MBATHA ${ }^{1}$, S. GATHOGO ${ }^{1}$, A.C. CHOTA², \\ H.B. MAGWISHA ${ }^{2}$, Z.E. MAKONDO ${ }^{2}$, E. RUKAMBILE ${ }^{2}$ and R. MWAKAPUJA ${ }^{2}$ \\ Veterinary Research Centre Muguga, Veterinary Sciences Research Institute, P. O. Box 32-00902, \\ Kikuyu, Kenya \\ ${ }^{1}$ Central Veterinary Laboratories Private Bag 00625, Kangemi, Kenya \\ ${ }^{2}$ Tanzania Veterinary Laboratory Agency (TVLA), Veterinary Complex, 131 Nelson Mandela Road, \\ P. O. Box 9254, 15487 Dar es Salaam, Tanzania \\ Corresponding author: jommugambi@gmail.com
}

\begin{abstract}
The zoonotic Mycobacterium bovis is a pathogen of significance in the dairy industry in many parts of the world. Although the pathogen primarily affects cattle, it has a wide host range including humans. A cross-sectional study was carried out in three agro-ecological zones of Tanzania, namely the southern highlands zone (SHZ), eastern zone (EZ) and northern zone (NZ), to examine the status of the disease in cattle, in order to inform control measures. A total of 391, 169 and 401 cattle were tested for bovine tuberculosis (bTB) in the SHZ, EZ and NZ respectively using the Single Intradermal Comparative Cervical Tuberculin Test (SICTT). Results showed that the prevalence of bTB was higher $(\mathrm{P}<0.05)$ in EZ 2.37\% $(\mathrm{n}=169)$ compared to SHZ $1.3 \%(\mathrm{n}=391)$ and NZ, where no positive result was recorded $(n=401)$. Thirty three cattle from SHZ and seven from EZ showed inconclusive results. In Kenya, 625 cattle from four sites within agro-pastoral and pastoral production systems were tested. In one area of Mwingi County, eastern Kenya, all the 161 cattle tested negative; while in the other three sites of Migori, in Nyanza, West Pokot and Laikipia in the Rift Valley, prevalence of 4-6\% was obtained with SICTT. Bovine TB occurs in the region and may pose a public health threat through occupational activities and/or consumption of animal products, especially since no obvious clinical signs were observed in positive animals. Policy issues on how to deal with positive cases, creation of awareness on this important zoonotic disease, and a simple test to quickly identify sick animals in the field require urgent attention.
\end{abstract}

Key Words: Agro-ecological zones, Mycobacterium bovis, Zoonoses

\section{RÉSUMÉ}

La bactérie zoonotique Mycobacterium bovis est un agent pathogène d'importance dans l'industrie laitière partout dans le monde entier. Bien que l'agent pathogène affecte essentiellement les bovins, il peut infecter une large range d'hôtes l'homme y compris. Une étude transversale a été réalisée dans trois zones agro-écologiques de la Tanzanie, notamment la zone Sud (SHZ), la zone Est (EZ) et la zone Nord (NZ), afin d'examiner la prévalence de cette maladie chez les bovins, en vue de définir des mesures pour son contrôle. Au total, 391, 169 et 401 bovins ont été testes pour la tuberculose bovine (bTB) respectivement dans le SHZ, EZ et NZ. Le test Intradermique Comparatif a la Tuberculine Cervicale (SICTT). Les résultats ont montré que la prévalence de bTB était élevée $(\mathrm{p}<0.05)$ en EZ 2.37\% $(\mathrm{n}=169)$ comparativement à SHZ 1.3\% $(\mathrm{n}=391)$ et NZ, ou aucun cas positif n'a été enregistre $(n=401)$. Trente-trois bovins de SHZ et 7 de EZ ont montre des résultats non conclusifs. Au Kenya, 625 bovins provenant de quatre sites au sein des systèmes de production agro-pastorale et pastorale ont été testes. Dans une zone de Mwingi a l'Est du Kenya, tous les 161 bovins ont été testes négative; tandis que dans les trois autres sites de Migori, en Nyanza, West Pokot et Laikipia dans la vallée du Rift, la prévalence était de 4$6 \%$ avec le test SICTT. La tuberculose bovine est présenté dans la région et peut engendrer des menaces de sante 
publique au travers des activités d'élevage et la consommation de viandes infectées, surtout qu'aucun signe Clinique évident n'a été observe chez les animaux dépistés positifs. Il est important et urgent de définir des mesures de gestion des cas positifs, de sensibiliser les populations sur les risques probables et de rendre disponibles des kits de tests rapides permettant d'identifier à temps les animaux atteints.

Mots Clés: zones Agro-écologiques, Mycobacterium bovis, Zoonoses

\section{INTRODUCTION}

Bovine tuberculosis (bTB), caused by Mycobacterium bovis bacterium, is found most commonly in cattle, but is also present in other domestic animals. It is zoonotic, meaning that it is transmissible between animals and humans (PAHO, 2001). The primary signs of bTB infection include persistent coughing, weakness and loss of weight. Symptoms result from the formation of tuberculous nodules in the lungs or the lymph nodes, particularly of the lungs and mammary glands; though can be found in any organ (OIE, 2009). The symptoms usually take months to develop in cattle, and infections can remain dormant for years, but are reactivated during periods of stress or in old age. Infected animals may develop a chronic, debilitating disease, whose severity varies with the dose of infectious organisms and individual immunity (OIE, 2009).

Although bTB is distributed worldwide, some countries have managed to control it by testing and slaughter of affected animals (Menzies and Neill, 2000; Cousins and Roberts, 2001); and by the end of 2001 Austria, Denmark, France, Germany, Luxembourg, Finland, Holland and Sweden were recognised to be free from the disease (Anonymous, 2001). Others have reported a reduction in prevalence, for example as documented in Spain (Alvarez et al., 2012).

Despite the great efforts and investments in the fight against the disease, bTB still persists in many other countries in the world (Reynolds, 2006), especially where wildlife reservoirs exist. In Africa, bTB represents a potential health hazard to both animals and humans, as nearly $85 \%$ of cattle and $82 \%$ of the human population live in areas where the disease is prevalent, or only partially controlled (Thoen and Steele, 1995).

Moreover, it is also present in wildlife (Cleaveland et al., 2005; Lekolool, 2011). A significant correlation between prevalence of $M$. bovis infection in humans and in local cattle populations was reported, thus highlighting the potential threat of this disease to humans (Daborn et al., 1996). The estimated prevalence of bTB in animals in countries like Tanzania, ranges across regions from 0.2 to $13.3 \%$ (Katale et al., 2012).

Lack of public awareness about the disease is considered to increase the risk of acquiring and spreading it (Lienhardt, 2001; Lienhardt $e t$ al., 2005). Lack of knowledge on disease transmission, clinical signs, and proper animal husbandry, as well as pastoralists' eating behaviour, not only expose animal and human populations to increased risk of contracting bTB, but also affects the control strategies (Shirima $e t$ al., 2003; Mfinanga et al., 2003; Onoja et al., 2010). Much more work on bTB has been published in Tanzania (Shirima et al., 2003; Cleaveland et al., 2007; Mwakapuja et al., 2013) than in Kenya, where studies are limited. The most recent one in Kenya was carried out in abattoirs and a prevalence of $2.05 \%$ of $M$. bovis was reported, although isolates of M. bovis were made from 19 out of 176 carcasses that had lesions suggestive of tuberculosis (Gathogo et al., 2012). The objective of this study was to assess knowledge on tuberculosis among pastoralists and agropastoralists; and document the presence of the disease in parts of Tanzania and Kenya.

\section{MATERIALS AND METHODS}

A cross-sectional study was conducted in areas of Tanzania and Kenya, where pastoral and agropastoral livestock keeping are practiced. Sample size was calculated using the standard formula for estimation of proportions (Martin et al., 1987).

Kenyan site. The Kenyan sites included Migori, Mwingi, Laikipia and West Pokot. Migori County is situated in the south-western part of Kenya and forms part of the border with Tanzania. Migori rises from 1,140 $\mathrm{m}$ at the shores of Lake Victoria in Nyatike, to 4,625 m in Uriri. Climate is 
inland equatorial that is modified by altitude, relief and Lake Victoria. Rainfall varies from 700 to 1800 mm annually (Hitaji Development Initiative, 2015). Indigenous breeds and some crosses constitute up to $95 \%$ of the cattle population in Migori. A more sedentary farming system is picking up in the county.

Mwingi site is located in Kitui county, with four agro-ecological zones of arid and semi-arid climatic types (Ministry of Devolution and Planning, 2013). The county is predominantly livestock rearing, but water scarcity and diseases pose formidable challenges. Rainfall pattern is bimodal, with the long rains (March to May) often erratic. The annual rainfall ranges from 300 to 1050 mm (Ministry of Devolution and National Planning, 2013).

West Pokot county is in the western zone of Kenya. Livestock farming is a favoured cultural practice. The county is mainly semi- arid to arid (Jaetzold et al., 2011).

Laikipia county lies between altitude $1,500 \mathrm{~m}$ above sea level at Ewaso Nyiro basin in the north, and $2611 \mathrm{~m}$ around Marmanet forest in the south. The Rift Valley, the Mt. Kenya and the Aberdares have significant effects on the climatic conditions of the county. The county is suitable for grazing and ranching besides having abundant wildlife (Laikipia County, 2013). It experiences a relief type of rainfall due to its altitude and location. The average annual rainfall varies from 400 to $750 \mathrm{~mm}$.

Site selection in Kenya. The study was conducted in sites within the four counties. The reasons for selecting the areas are shown in Table 1.

Fields to be visited were randomly selected, with the assistance of field veterinary personnel. A maximum of three cattle were tested in each of the test farms. Majority of the tested animals were females. A total of 625 cattle were screened, of which 124 were from Migori, 78 from West Pokot, 262 from Laikipia and 161 from Mwingi counties.

Tanzanian sites. The Tanzanian study sites included southern highlands zone (SHZ), eastern zone (EZ) and northern zone, cutting across three agro-ecological zones. Generally, altitude modifies climatic conditions; SHZ and NZ receive an average of 1,250 $\mathrm{mm}$ rainfall and in EZ rainfall ranges between 750 and 1,250 mm per annum. Mean temperature ranges from 20 to $26^{\circ} \mathrm{C}$ in January and from 16 to $22^{\circ} \mathrm{C}$ in July; the coolest being in northern and southern highlands and the warmest being in the eastern zone along the coast (Mbululo and Nyihirini, 2012).

Cattle were randomly picked from 256 selected villages. Milking cows and heifers were targeted during selection. In a few exceptional cases, bulls (such as owned by a group of farmers) were also screened. A total of 961 cattle were screened and of these, 391 were from SHZ, 401 from NZ and 169 from EZ.

bTB screening. Cattle were restrained in crushes and prepared for intradermal inoculation, as recommended by the Tuberculin Test Kit's manufacturer. Briefly, the cattle were visually examined for obvious skin swellings or clinical signs of tuberculosis. An area within the middlethird of the neck was then marked for shaving. On each animal, two areas about $10 \mathrm{~cm}$ apart were shaved and the cut hair and debris brushed off using water, in order to allow for the injection of avian, as well as bovine purified protein derivatives (PPD) of Mycobacterium avium and Mycobacterium bovis, respectively. The proteins were injected on either of the two shaved skin sites.

Before injecting the proteins, a fold of skin at each of the intended clipped injection sites was

TABLE 1. Reasons for selection of County to include in the study in Kenya

\begin{tabular}{ll}
\hline Site & Reason for choice \\
\hline Laikipia & Earmarked as a disease free zone and flagship county for livestock export in government plans \\
Mwingi & Situated along an important cattle route \\
Migori & Anecdotal information of a TB problem in the area \\
Pokot & Milk is not necessarily boiled before consumption \\
\hline
\end{tabular}


measured with a pair of callipers. A $0.1 \mathrm{ml}$ volume of avian PPD and of bovine PPD was delivered intra-dermally, using a $1 \mathrm{ml}$ tuberculin syringe. The area was palpated to feel the presence of a small swelling, indicative of intradermal injection (OIE, 2009).

The skin fold thickness at each injection site was measured at $72 \mathrm{hr}$ post-inoculation. The same person carried out all the measurements at any one study site to maintain consistence of measurements. Differences in the magnitude of swellings between the avian and the bovine PPD injection sites were recorded. All inconclusive results were re-tested after 42 to 60 days as recommended by OIE (2009). However, in this study, re-testing was only done in Migori county in Kenya due to logistical constraints.

Table 2 shows the criteria for interpreting the results. The data were recorded and organised using Microsoft Excel 2010. Statistical analysis was carried out using Epi Info 7 Statistical Software. MedCalc ${ }^{\circledR}$ statistical software was used to compare proportions of the variables. Statistical significance between variables was examined using $\mathrm{P}$-value at a probability of $\mathrm{P}<0.05$ for the Tanzanian data.

\section{RESULTS}

For all cattle screened in Tanzania and Kenya, there was no report of obvious clinical signs of bTB. However, upon testing with SICTT, while some animals had hardly any discernible swellings, others had diffuse, oedematous, warm and painful swellings at the injection sites. In Kenya, prevalences of 4, 5 and $6 \%$ were recorded in Migori, Laikipia and West Pokot counties, respectively; while no positive cases were obtained in Mwingi (Table 3).

In Tanzania, prevalences of 2.37 and $1.28 \%$ were recorded in EZ and SHZ, respectively (Table 3 ). No positive cases were recorded in NZ, where 401 cattle were screened. Relatively high percentages of inconclusive results were also

TABLE 2. Criteria for interpreting the comparative intradermal tuberculin test results (adapted from Annex B of Council Directive 64/432/EEC and OIE, 2009)

\begin{tabular}{ll}
\hline Result & Difference between thickness $(\mathrm{mm})$ of bovine and avian PPD injections after $72 \mathrm{hr}$ \\
\hline Positive & A reaction to bovine tuberculin PPD which is more than $4 \mathrm{~mm}$ compared to the reaction to avian PPD \\
Inconclusive & A reaction to bovine tuberculin PPD of at least $2 \mathrm{~mm}$ which is $1-4 \mathrm{~mm}$ greater than the reaction to avian PPD \\
Negative & A reaction to bovine tuberculin PPD which is equal to or less than $1 \mathrm{~mm}$ the reaction to avian tuberculin PPD \\
\hline
\end{tabular}

TABLE 3. Summary bTB test results in Kenya and Tanzania of inconclusive results

\begin{tabular}{lccccc}
\hline Site & No. tested & No. positive & No. inconclusive & Prevalence (\%) & Inconclusive (\%) \\
\hline Tanzania & & & & & \\
SHZ & 391 & 5 & 7 & 1.28 & 8.44 \\
NZ & 401 & 0 & 0 & 0.00 & 0.00 \\
EZ & 169 & 4 & 33 & 2.37 & 4.14 \\
Total & 961 & 9 & 40 & 0.93 & 4.16 \\
Kenya & & & & & \\
Migori & 124 & 5 & 25 & 4.03 & 20.16 \\
West Pokot & 78 & 5 & 26 & 6.41 & 0 \\
Laikipia & 262 & 13 & 0 & 4.96 & 0 \\
Mwingi & 161 & 0 & 0 & 0 & 0.16 \\
Total & 625 & 23 & 51 & 3.68 & 0 \\
\hline
\end{tabular}


recorded: 20.16 and $33.33 \%$ in Migori and West Pokot, and 8.44and $4.14 \%$ in SHZ and EZ, respectively. Retesting of 26 animals in Migori showed that six more (24\%) out of 25 cattle were positive, raising the prevalence to $8.9 \%$. One animal was not presented for reading after $72 \mathrm{hr}$ following re-testing. The owner did not disclose its whereabouts.

\section{DISCUSSION}

Our study has confirmed that bovine TB still exists in Tanzanian cattle. The prevalence was $1.28 \%$ in SHZ and $2.37 \%$ in EZ and this is the first report of bTB in the two areas. The prevalences, though lower than those reported earlier by Shirima et al. (2003) and Mwakapuja et al. (2013) in different localities of the country; are within the estimated prevalence of 0.2 to $13.3 \%$ across regions in the country (Katale et al., 2012). Prevalences are unlikely to be uniform throughout a country (Alvarez et al., 2012).

In Kenya, bTB is classified as "notifiable" under the Animal Diseases Act. The results showed that the disease was present in three of the Kenyan study sites, with prevalences of 4 to $6 \%$. They indicated the occurrence of the disease in areas not reported previously to have the disease. Re-testing by SICTT in Migori resulted in $24 \%$ of positive reactors, suggesting that the prevalence might be higher than what is reported here.

Similar findings were reported in Brazil when six out of seven inconclusive cases by the skin test, were positive by PCR and culture (Zarden et al., 2013). Medeiros et al. (2010) reported that anergic animals may be harbouring TB, yet were not reactive to the skin test; while delayed hypersensitivity may take 3 to 6 weeks, following infection (OIE, 2009). These are probable reasons for obtaining inconclusive results in this study.

Lekolool (2011) investigated the epidemiology of $M$. bovis in the wildlife-livestock interface to determine the prevalence and spatial distribution in Masai Mara and Amboseli ecosystems. With the gamma interferon assay, the overall prevalence in wildlife was $14.8 \%$ compared to $2.3 \%$ among the livestock. This is of epidemiological significance since some wild animals may have a role in the spread of the disease to other wild and domestic animal species (Shitaye et al., 2007). Mycobacterium bovis has been associated with human extra pulmonary tuberculosis.

Mycobacterium bovis accounts for only $1 \%$ of all human TB in developed countries, compared to $10 \%$ in the developing world (Etchechoury et $a l ., 2010)$. In Tanzania, one of the few developing countries with quantitative data on the prevalence of $M$. bovis, there was a significant increase $(116.6 \%)$ in extra-pulmonary cases reported between 1995 and 2009, suggesting the possibility of widespread $M$. bovis infection. In the southern highlands region of the country, $M$. bovis was isolated from $1 / 23(4 \%)$ cases of pulmonary TB, from 6/21 (28.6\%) cases of cervical adenitis and from $7 / 65$ (10.8\%) of culture-positive cases of cervical adenitis in the Arusha region. Since extra-pulmonary TB cases comprise 15-20\% of new cases of TB recorded each year in Tanzania, M. bovis may not be a negligible component of the human tuberculosis epidemic (Cleaveland et al., 2007). That bTB contributed substantially to the burden of human extrapulmonary tuberculosis in Tanzania is worrying, given that $M$. bovis is resistant to pyrazinamide, one of the four first line TB antibiotics and prognosis is often poor (WHO, 2010).

In Tanzania, ignorance of farmers about the disease and how it spreads, coupled with culture and uncontrolled movement of animals, are important risk factors (Dr. Andrew Chota Veterinary Laboratory Agency, Tanzania: personal communication). The lack of clear policies on how bovine tuberculosis can be controlled, and the failure of health authorities to associate cattle with tuberculosis, hinder the control of the disease. Furthermore, the disease which is considered neglected has not even been classified as notifiable in the country (Kazwala et al., 2006). However, the present results indicate a rather low prevalence of bTB, and implies low risk to humans in the study areas.

Findings have shown that pastoral and agropastoral communities are at the greatest risk from bTB and brucellosis. Furthermore, people with poor levels of knowledge living in remote, marginalised areas are particularly at high bTB risk (WHO, 2010). Public awareness of hygienic measures, that can substantially reduce the risk 
of diseases in these settings, is often very limited (World Bank, 2010a). A questionnaire study that preceded the SICTT reported here, showed that awareness was very limited. The hygienic conditions and sanitary services available to dispose waste water and organic material in slaughter houses was wanting in some places within the study sites. During this study, sensitisation meetings were held and more of these need to be held.

Success in reducing the public health significance of zoonotic diseases, greatly depends on the level of cooperation between medical and veterinary sectors, in the diagnosis of zoonoses, exchange of information, organisation of shared surveillance systems, common training of staff and creation of community awareness (WHO, 2003). Hygienic measures are recommended for the control of TB among cattle. The infected animal, which is a potential source of infection, should be identified through periodic application of the intradermal tuberculin test and removed from the herd by destruction or by segregation. However, the policy to support this action is not in place in either country. Lately, the practice has received severe criticism because of costs and chances of falsely condemning healthy, high value cattle and of missing infected ones. Coupled with this is the view that the reaction to the skin test could actually be a sign of immunity rather than of sickness (Ritchie et al., 2011).

Vaccination is an important tool to control bTB, but the efficacy of the BCG vaccine in cattle was reported to vary from 56 to $68 \%$, depending on the parameter measured (Ameni et al., 2010); moreover, it has not been approved for use. The presence of maintenance hosts in wildlife populations also impedes bTB eradication programmes (Etter et al., 2006) and wild animals too have to be considered in the programmes. However, it is prudent to control the disease because of the high pay-off and costeffectiveness of control interventions for zoonotic diseases (Coleman et al., 2004; Budke, 2006; Fevre et al., 2008). Significant benefits that accrue from improved prevention and control measures of a disease, outweigh the cost of investing in the necessary animal health services (OIE, 2007). For example, in Africa, it has been estimated that an investment of Euro 14.7 million to control CBPP could save Euro 30 million annually in losses from morbidity/mortality, leading to a net benefit of Euro 15.4 million (World Bank, 2010b).

From the observations made during the course of this study, it is necessary to use knowledge dissemination methods that take in account illiteracy and poor visual literacy. It is also important to involve and interest political leaders and other advocates, establish and implement regulatory structures for sale of milk, and develop an integrated national policy for control of bovine tuberculosis. Bovine-induced human tuberculosis, brucellosis, and echinococcosis are major causes of morbidity and mortality among poor people, although they are also almost certainly the most under-reported diseases (World Bank, 2010b).

The intradermal tuberculin skin test is recommended by the OIE for international trade (OIE, 2009), although it is not $100 \%$ reliable. However, delayed hypersensitivity may not develop for a period of 3-6 weeks following infection. Thus, if a herd/animal is suspected to have been in recent contact with infected animals, testing should be delayed in order to reduce the probability of false-negative reactions (OIE, 2009). A number of blood tests are available; these include the gamma interferon and the lymphocyte proliferation assays that test cellular immunity; and the ELISA that tests humoral immunity. Due to the cost and more complex nature of laboratory-based assays, these are usually used as ancillary tests to maximise the detection of infected animals, or to confirm or negate the results of an intra-dermal skin test (OIE, 2009). PCR based tests, using geneXpert machines, are now available in the human diagnostic laboratories.

\section{CONCLUSION}

The prevalences of bTB of $1.28 \%$ and $2.37 \%$ in Tanzania are lower than the $4-6 \%$ obtained in Kenya. The relatively high number of inconclusive results seems to indicate anergy or a delay in reactions, and is likely to under-state the real prevalence. A more accurate, easy to use test is required. In the positive animals, no obvious 
clinical signs of the disease are evident, making it difficult for farmers to easily appreciate the significance of bTB. No policies appear to be in place to effectively control bTB in either country. The test and slaughter policy that is used in other countries to control and possibly eradicate the disease, has lately come under scrutiny in terms of effectiveness and rationale and efficacious vaccines are required.

\section{ACKNOWLEDGEMENT}

This study was conducted with funds from the Eastern Africa Agricultural Productivity Project (EAAPP). In Kenya, the support from the Director General of Kenya Agriculture and Livestock Research Organization (KALRO) is acknowledged. Thanks to the Chief Executive Officer (CEO) of Tanzania Veterinary Laboratory Agency (TVLA) for granting permission for sample storage and analysis and the Association for Strengthening Agricultural Research in Eastern and Central Africa (ASARECA) for facilitating the publication of this paper.

\section{REFERENCES}

Alvarez, J., Perez, A.M., Bezos, J., Casal, C., Romero, B., Rodriguez-Campos, S., SaezLiorente, J.L., Diaz, R., Carpintero, J., de Juan, L. and Dominguez, L. 2012. BMC Veterinary Research 8: 100.

Ameni, G., Vordermeier, M., Aseffa, A., Young, D.B. and Hewinson, R.G. 2010. Field evaluation of the efficacy of Mycobacterium bovis Bacillus Calmette-Guérin against Bovine Tuberculosis in Neonatal Calves in Ethiopia. Clinical and Vaccine Immunology. doi:10.1128/CVI.0022210.

Anonymous, 2001. http://ec.europa.eu/food/ food/biosafety/s a l monella/01_ mycrobacteria_2001.pdf)

Budke, C. M. 2006. Global Socioeconomic Impact of Cystic Echinococcosis. Emerging Infectious Diseases 12(2):296-303.

Cleaveland, S., Mlengeya, T., Kazwala, R.R., Michel A., Kaare, M.T., Jones, S.L., Eblate, E.,Shirima, G.M. and Packer, C. 2005. Tuberculosis in Tanzanian Wildlife. Journal of Wildlife Diseases 41(2): 446-453.
Cleaveland, S., Shaw, D.J., Sayoki G., Mfinanga, S.G., Shirima, G., Rudovick R., Kazwala, R.R., Eblate, E. and Sharp, M. 2007. Mycobacterium bovis in rural Tanzania: Risk factors for infection in human and cattle populations. Tuberculosis 87: 30"43. http://dx.doi.org/ 10.1016/j. tube.2006.03.001

Coleman, P.G., Fevre, E.M. and Cleaveland, S. 2004. Estimating the public health impact of rabies. Emerging Infectious Diseases 10(1):140-142.

Cosivi, O., Grange, J.M., Daborn, C.J., Raviglione, M.C., Fujikura, T., Cousins, D., Robinson, R.A., Huchzermeyer, H.F.A.K., de Kantor, I., and Meslin, F.X.1998. Zoonotic Tuberculosis due to Mycobacterium bovis in Developing Countries. Emerging Infectious Diseases 4(1): 59-70.

Cousins, D.V. and Roberts, J.L. 2001. Australia's campaign to eradicate bovine tuberculosis: the battle for freedom and beyond. Tuberculosis (Edinb) 81:5-15.

Daborn, C.J., Grange, J.M. and Kazwala, R.R. 1996. The bovine tuberculosis cycle-an African perspective. Journal of Applied Bateriology (Suppl)81:27s-32s. 2008: Doi: 10.1111/j.13652672.1996.tb04595.x

Etchechoury, I., Echeverrýa Valencia, G., Morcillo, N., Sequeira, M.D., Imperiale, B. López, M., Caimi, K., Zumárraga, M.J., Cataldi, A. and Romano, M.I. 2010. Molecular typing of Mycobacterium bovis isolates in Argentina: First description of a person-to-person transmission case', Zoonoses Public Health 57: 375^381. http://dx.doi.org/10.1111/j.18632378.2009.01233.x

Etter, E., Donald, P., Jori, F., Caron, A., Goutard, F. and Roger, F. 2006. Risk analysis and bovine tuberculosis, a re-emerging zoonosis. Annals of the New York Academy of Sciences 108: 61^73. http://dx.doi.org/10.1196/annals. 1373.006

Fevre, E.M., Odiit, M., Coleman, P.G., Woolhouse, M.E. and Welburn. S.C. 2008. Estimating the burden of Rhodesiense sleeping sickness during an outbreak in Serere, Eastern Uganda. BMC Public Health 8:96.

Gathogo, S.M., Kuria, J.K. and Ombui, J.N. 2012. Prevalence of bovine tuberculosis in slaughter cattle in Kenya: A postmortem, 
microbiological and DNA molecular study. Tropical Animal Health and Production 44(7):1739-1744.

Hitaji Development Initiative. 2015. About Migori County. http://hitaji.org/about-hdi/aboutmigori-county/

ICID. 2010. Tanzania Country Profile. http:// www.icid.org.

Jaetzold, R., Schimdt, H., Berthold, H. and Shisanya, C. 2011. Farm Management Handbook of Kenya Vol. II. Natural conditions and farm management information $2^{\text {nd }}$ Ed. Part B Subpart B1b Northern Rift Valley Province. Ministry of Agriculture, Kenya and German Agency for International Cooperation (GIZ)

Katale, B.Z., Mbugi, E.V., Kendal, S., Fyumagwa, R.D., Kibik, G.S., Godfrey-Faussett, P., Keyyu, J.D., van Helden, P. and Matee, M.I. 2012. Bovine tuberculosis at the human-livestockwildlife interface: Is it a public health problem in Tanzania? A review. Onderstepoort Journal of Veterinary Research 79(2). http:/ /dx.doi.org/10.4102/ojvr.v79i2.463

Kazwala, R.R. 1996. Molecular epidemiology of bovine tuberculosis in Tanzania. $\mathrm{PhD}$. Thesis, University of Edinburgh, Edinburgh, UK. 317pp.

Kazwala, R.R., Kusiluka, L.J.M., Sinclair, K., Sharp, J.M. and Daborn, C.J. 2006. The molecular epidemiology of Mycobacterium bovis infections in Tanzania. Veterinary Microbiology112:201"210. http://dx.doi.org/ 10.1016/j.vetmic.2005.11.026

Laikipia County, 2013. First County Integrated Development Plan 2013-2017, Kenya Vision 2030.

Lekolool, I.L. 2011. Epidemiological investigation of bovine tuberculosis in the wildlifelivestock interphase in the Masai Mara and Amboseli ecosystems of Kenya M.Sc. Thesis, University of Nairobi, Nairobi, Kenya.

Lienhardt, C. 2001. From exposure to disease: The role of environmental factors in susceptibility to and development of tuberculosis. Epidemiological Reviews 23: 288-301.

Lienhardt, C., Fielding, K., Bah, B., Gustafson, P., Warndorff, D., Palayew, M., Lisse, I. and Donkor, S. 2005. Investigation of the risk factors for tuberculosis: A case-control study in three countries in West Africa.
International Journal of Epidemiology 34(4):914-923.

Martin, S.W, Meek, H.A. and Willeberg, P. 1987. Veterinary epidemiology: Principles and Methods. Iowa State University Press, Ames, Iowa, USA. p. 45.

Mbululo, Y. and Nyihirani, F. 2012. Climate characteristics over Southern Highlands Tanzania. Atmospheric and Climate Sciences 2:454- 463.

Medeiros, L.S., Marassi, C.D., Figueiredo, E.E.S. and Lilenbaum, W. 2010. Potential application of new diagnostic methods for controlling bovine tuberculosis in Brazil. Brazilian Journal of Microbiology 41:531-541.

Menzies, F.D. and Neill, S.D. 2000. Cattle-to-cattle transmission of bovine tuberculosis. Veterinary Journal 160: 92-106.

Mfinanga, S.G., Mørkve, O., Kazwala, R.R., Cleaveland, S., Sharp, J.M., Shirima, G. and Nilsen, R. 2003. Tribal differences in perception of tuberculosis: a possible role in tuberculosis control in Arusha, Tanzania. International Journal of Tuberculosis and Lung Disease 7:933-941.

Ministry of Devolution and Planning. 2013. Kitui County Development Profile, Government of Kenya, Nairobi, Kenya.

Mwakapuja, R.S., Makondo, Z.E., Malakalinga, J., Bryssinckx, W., Mdegela, R.H., Moser, I., Kazwala, R.R. and Tanner. M. 2013. Prevalence and significant geospatial clusters of bovine tuberculosis infection at livestock-wildlife interface ecosystem in Eastern Tanzania. Tropical Animal Health and Production 45:1223-1230. DOI 10.1007/s11250-013-03502.

OIE. 2007. Prevention and control of animal diseases worldwide. Feasibility study - A global fund for emergency response in developing countries. Civic Consulting Alleweldt and Kara GbR, Berlin, Germany.

OIE. 2009. Bovine Tuberculosis Ch. 2.4.7 OIE Terrestrial Manual.

Onoja, I.I., Ogunkoya, A.B., Kudi, C.,Okpapi, J.U. and Cadmus, S.I.B. 2010. Tuberculosis transmission amongst pastoralists in Kaduna State, Nigeria. Sokoto Journal of Veterinary Sciences 8:12-17. 
PAHO. 2001. Zoonoses and communicable diseases common to man and animals. Bacterioses and Mycoses. $3^{\text {rd }}$ ed. Vol. 1, Washington, DC.p. 378. http://www. paho.org/hq

Reynolds, D. 2006. A review of tuberculosis science and policy in Great Britain. Veterinary Microbiology 112:119-126.

Ritchie, M., Hall, S., Griffiths, M. and Brown, Y. 2011. Bovine TB time for a rethink. Website: http://www.rethinkbtb.org

Shirima, G.M., Kazwala, R.R. and Kambarage, D.M. 2003. Prevalence of bovine tuberculosis in cattle in different farming systems in the eastern zone of Tanzania. Preventive Veterinary Medicine 57:167-172.

Shitaye, J.E., Tsegaye, W. and Pavlik, I. 2007. Bovine tuberculosis infection in animal and human populations in Ethiopia: A review. Veterinarni Medicina 52: (8): 317-332

Thoen, C.O. and Steele, J.H. 1995 Mycobacterium bovis infection in animals and humans. ${ }^{\text {st }}$ Ed. Iowa State University Press, USA. 355 pp.
WHO. 2003. Main challenges in the control of zoonotic diseases in the eastern Mediterranean region. Technical Paper EM/ RC50/7.

WHO. 2010. Global tuberculosis control, global, region and country-specific for key indicators. Website: http:// www.who. int/tb/data

World Bank. 2010a. People, pathogens and our planet, Volume 1: Towards a one health approach for controlling zoonotic diseases. Agriculture and rural development health, nutrition and population Report No. 50833GLB. 74pp.

World Bank. 2010b. People, pathogens and our planet, Volume 2: Economics of one health. Agriculture and rural development Report No. 69145-GLB PT.

Zarden, C.F.O., Marassi, C.D., Carvalho, A.C., Figueiredo, E.E.S. and Lilenbaum, W. 2013. Bacteriological and molecular detection of Mycobacterium bovis in cattle with inconclusive results to intradermal tuberculin tests. Epidemiology and Infection 141: 13901393. 